\title{
The traction of lean production on halal food integrity
}

\begin{abstract}
The trade-off between cost and quality has been debated widely in food literature. Within this context, the lean approach has been debated for balancing these two dichotomies. At the same time, consumers are facing increasing food integrity issues such as the horsemeat scandal in the UK or melamine milk contamination in China. It seems that cost and quality lie in opposite directions. Or do they?

This paper aims to investigate and establish how lean could help managers to achieve the cost and quality balance. The research will especially study lean applicability in safeguarding the integrity of the credence quality attribute of food products, e.g. kosher, halal or organic food, while maintaining low cost.

Case studies covering seven food supply chains were used to examine how and when lean leads to low food integrity; and compels with high food integrity. The results provide strong empirical evidence for lean application and for opening a new lean horizon in the food supply chain. Furthermore, the paper will discuss how firms could juggle between cost, quality and integrity, whilst staying competitive.
\end{abstract}

Volume 5 Issue 4 - 2017

\author{
Mohd Helmi Ali,' Kim Hua Tan, ${ }^{2}$ Norhidayah \\ Suleiman, ${ }^{3}$ Syed Shah Alam' \\ 'Faculty of Economics and Management, School of Management, \\ Universiti Kebangsaan Malaysia, Malaysia \\ ${ }^{2}$ The University of Nottingham, Nottingham University Business \\ School Jubilee Campus, UK \\ ${ }^{3}$ Department of Food Technology, Faculty of Food Science and \\ Technology, Universiti Putra Malaysia, Malaysia
}

Correspondence: Mohd Helmi Alia, Faculty of Economics and Management, School of Management, Universiti Kebangsaan Malaysia, Malaysia, Email mohdhelmiali@ukm.edu.my

Received: March 23, 2017 | Published: December 27, 2017

Keywords: lean, food integrity, halal

\section{Introduction}

The scandals of horsemeat in the United Kingdom and melamine milk in China raise doubt over the honesty of food labelling. Responding towards the impact of the scandals, many firms currently address public doubt by using attractive "marketing" such as $100 \%$ beef, $100 \%$ UK products and exclusions, e.g. this product may contain nuts. The product associated with the lethal impact on health such as in the melamine milk scandal is an explicit case which is easier to detect and mitigate. However, despite that, the production of credence quality attribute products like halal and kosher requires an extra vigilance for wholesomeness during the process along the supply chain. ${ }^{1-3}$ The inability to ascertain and evaluate the product characteristic by individual customers (even after its consumption) daunts the task of ensuring the quality and integrity of the food. The shortfalls leave voids for manipulation, especially on the integrity aspects which are a relatively new concept and not comprehended by all. ${ }^{4}$ Furthermore, an extra added value on the product will directly influence the total cost of production.

Seen in the light of the food supply chain complexity, the disadvantage involved in ensuring credence quality, and the impact of its safeguarding towards the total cost, a lean enterprise model is sought to be the basis of the study in achieving a cost and quality balance. In this essence, the model that is defined by Womack et al. ${ }^{5}$ as an operationally synchronized company is seen as suitable when credence quality requires wholesomeness in its production. Furthermore, very little is known of lean applicability in the food industry. ${ }^{6}$ Thus, this paper aims to corroborate towards the conventional wisdom of lean goals in the context of halal food industries within the perspective of balancing cost and quality.

Lean application can be very difficult due to the nature of food industries that have large batches process. ${ }^{7,8}$ The industry requires a long forecast as the breeding and farming of the raw materials require a significant time for production. In the same essence, the disproportion between demand and production is highly expected and may lead to overproduction, higher inventory, and even short production. Therefore, a lean implementation can be problematic in the food industry. Exacerbating that, the food quality control concept is expected to cover from "farm to fork" 9,10 making it more challenging as there are no power and leverage resources to allow the lean approach to be implemented along the supply chain. ${ }^{11}$

Applying lean in the food industry can start with implementation of $5 \mathrm{~S}$ housekeeping in preparing for the wider concept of lean production. ${ }^{12}$ A better organized workplace equipped with visual signalization, bulletin boards, daily demands, etc. helps in foreseeing the upcoming problems and allow reactions in due time in order to keep the production flow continuous. Seen in this light, $5 \mathrm{~S}$ is also significant with credence product quality control; for example, the update of the ingredients halal certification status used in the production. There are few cases where the certificate for certified halal food products has been revoked, and where the contamination or mixture of the non-halal type of product with other halal products has jeopardized the integrity of the halal status of the product. The necessary wastage that occurs during the production of halal food, such as transhipment of the product (to reduce the risk of logistics), storage and inventory (to reduce the risk of contamination), lead time (to reduce the risk of food security), etc. can be addressed from the reorganization of the workplace and/or cell layout. ${ }^{12}$

The example indicates that lean principles have a significant role in the food processing industries where it can reduce cost and increase the overall efficiency, and especially food integrity. ${ }^{13}$ However, if seen from a production perspective, current food production is almost justin-time and possibilities for improvement seem very small. 
Despite lean implementation benefitting other industries like the automotive and manufacturing industries, Cox et al. ${ }^{11}$ highlight that commercial return for all involved companies in the chains working together and adopting lean principles turn out less than expected. This is further supported by Lehtinen et al. ${ }^{6}$ the applied lean tools used in the study pointed out the important problems in the process, i.e. they showed that the impact of the production processes on the costs and value added time is very small, and waste is everywhere, especially in inventories.

Credence quality attribute products like kosher and halal foods for instance, have more specific and stringent production requirements that are required to be followed. The additional requirements, such as a special labour force (slaughter person), special machinery (stunner and special knife), dedicated transporter (halal and kosher transporter), dedicated space for inventory, etc. significantly contribute towards the extra cost in production. Food production is a continuous process which restricts the set of the operations and machines, which are impractical to move, resulting in a requirement for higher investment. ${ }^{7}$ Even though the constant demand leads to a continuous flow, eventually reducing work in progress and finished goods inventory, ${ }^{12}$ the integrity aspect of kosher and halal foods is far from over, as it should be compelled with the "farm to fork" concept, which reflects a broader scope of context. In contrast, the demand for an individual producer is often variable and there are no strict contracts (the halal certification is voluntary) which would enable stable flow of products through the system and supply chain; thus it is difficult to ensure JIT (Just in Time) in different stages ${ }^{11}$ by a certified halal or kosher producer.

\section{Methodology}

\section{Theoretical sampling}

We decided to do the study on halal food because of the following compelling reasons:

i. Halal food shares many important common processes with nonhalal food, thus halal food integrity can shed light on other food supply chains.

ii. Halal food accounts for more than $17 \%$ of the world food industry.

iii. Halal food markets are growing. In ensuring comparability between the firms, theoretical sampling is done through the characterization of the firm that has been certified by JAKIM (Government of Malaysia's halal certification body) with a private limited status. Seven leading brand firms from different Malaysian' consumers preference was finally agreed to participate the study as shown in Table 1, that fell within the often-suggested sample size of four to tens cases in the interview methodology. ${ }^{14}$

\section{Data collection}

In-depth interviews were carried out with key informants, ranging from 45 minutes to 2hours, and were performed in English. The interview questions were derived from existing lean literature (i.e., ${ }^{11,12}$ and being applied into halal food perspective. The interview was done in English language preceded by email notifications. All the interviews were comprehensively note taking and transcribed afterwards. In addition, the interviews are also tape recorded to avoid researcher bias in data collection and analysis.
Table I Sample

\begin{tabular}{|c|c|c|c|c|c|}
\hline Case & Category & Prod & Outlet & Informant & $\begin{array}{l}\text { Yrs in } \\
\text { post }\end{array}$ \\
\hline A & Fast Food & 181 & 457 & $\begin{array}{l}\text { Senior General } \\
\text { Manager }\end{array}$ & 7 \\
\hline B & Fast Food & 141 & 188 & $\begin{array}{l}\text { Purchasing } \\
\text { Manager }\end{array}$ & 15 \\
\hline $\mathrm{C}$ & Casual Dining & 190 & 117 & Halal Executive & 3.4 \\
\hline D & Casual Dining & 245 & 42 & $\begin{array}{l}\text { Operation } \\
\text { Manager }\end{array}$ & 10 \\
\hline $\mathrm{E}$ & Coffee House & 531 & 151 & $\begin{array}{l}\text { Senior Halal } \\
\text { Executive }\end{array}$ & 5 \\
\hline $\mathrm{F}$ & $\begin{array}{l}\text { Fresh Processed } \\
\text { Meat Product }\end{array}$ & 76 & 0 & $\begin{array}{l}\text { Islamic Related } \\
\text { Officer }\end{array}$ & 2 \\
\hline G & $\begin{array}{l}\text { Fresh Processed } \\
\text { Meat Product }\end{array}$ & 27 & 0 & $\begin{array}{l}\text { Halal Co- } \\
\text { ordinator }\end{array}$ & 5 \\
\hline
\end{tabular}

\section{Data analysis}

The data was analyzed in two stages, firstly within case analysis and followed by between case analyses. A within-case analysis is done to examine the lean and halal integrity in a single context, meanwhile the across case analysis is done as for the replication for testing the construct of interest in the other setting. During within case analysis, description consistency of each case is generated through all relevant information on the practitioners related to lean implementation in safeguarding the halal integrity. The similarity and variety in the cases were a deliberate research design strategy chosen to increase the external validity of the study's findings, and to ensure the findings were generalizable and not specific to any one type of process or market. ${ }^{15}$

\section{Results and discussion}

The study focuses on lean implementation in safeguarding the integrity of halal food. In summary, Table 2 shows that the lean implementation has been at least implemented in the firm. Thus, we are shaping the argument according to the most significant and commonly mentioned goals in halal food integrity perspectives: improving quality, i.e. understanding the consumer's demands and needs; design processes to meet the expectations and requirements; and reducing total cost, i.e. produce only to consumer demand.

Table 2 Summary of key lean performance themes derived from the interviews

\begin{tabular}{lccccccc}
\hline Items & A & B & C & D & E & F & G \\
\hline Halal quality & $\mathrm{X}$ & $\mathrm{X}$ & $\mathrm{X}$ & $\mathrm{X}$ & $\mathrm{X}$ & $\mathrm{X}$ & $\mathrm{X}$ \\
Halal processing & & $\mathrm{X}$ & $\mathrm{X}$ & & & $\mathrm{X}$ & \\
Production cost & $\mathrm{X}$ & & $\mathrm{X}$ & $\mathrm{X}$ & & $\mathrm{X}$ & \\
\hline
\end{tabular}

\section{Lean and meeting halal quality}

The major insight obtained from the study was the quality aspect of halal food. The product's halal quality should at all times be maintained throughout the process and supply chain in ensuring its integrity. However, the cases highlight the difficulties in maintaining halal quality in its complex supply chain:

“(...) is facing problems regarding controlling the imported raw 
materials and we are unable to fully ensure the raw materials sourced are halal" (case F).

Seen in this light, the supply chain improvements should be done for the sake of customers in ensuring halal food integrity. Despite the claims of the unstable flow products in the supply chain which inhibit lean application, there is always room for improvement. For instance, the value adding activities (halal processing) are what customers (Muslims) are willing to pay for; elsewhere wastes can be leaned through.

\section{Lean and halal design process interfaces}

"We appoint and control our own distributor. All information will come from head-quarters such as list of suppliers the distributor can sourced, the specific prices on the supply, types of products, and so on (...) the distributor is different entity than us (...)" (case B).

The example shows that lean implementation in ensuring food integrity can be successful by fulfilling most of the principles highlighted by Spear et al. ${ }^{16}$

i. The work is highly specified by imposing halal quality control in the supply chain, sequencing and timing of process are determined by information from the headquarters.

ii. The customer-supplier connection is direct where the appointment of the supplier and the communications are controlled by the focal company.

iii. The pathway of the product and services is simplified as the selection of supplier is done in advance. However, there is very little room to leverage improvements on scientific methods in ensuring halal integrity, as there are very limited scientific ways in ascertaining whether food is halal or not. ${ }^{17}$ In the same line of reasoning, it is detected that the focal firms are over reliant on the halal certification mechanism without focusing the philosophy and culture of lean in the supply chain. It is highly probable that lean practice is implemented in the same way.

"We are relying massively to the (...) halal certification body in certifying product" (case F)

“(...) we do not do any extra audit as it is JAKIM role (...) we just make sure they have halal certificates (...)"( case C).

Furthermore, the food industry has to compromise on employee turnover, which eventually affects halal food integrity once the lean are implemented.

\section{Cost-cutting through lean and its applicability in hala food}

On the other hand, the goal of reducing total cost using lean while safeguarding integrity is a daunting task for the halal focal company. It is important to highlight the nature of the food industry, which comprises large batches, long forecast, and high disproportion between demand and supply, leading to high levels of wastefulness in halal food production, i.e. overproduction (push system production), high inventory (large batches production), over processing (higher and stringent halal requirements), defects (ensuring the halal conformance efforts), waiting (halal certification approval), or not meeting consumer demand or specification. In managing the wastage, there are many ways that halal food integrity can be jeopardized if not governed carefully. The push system has leaded the focal companies to source the materials from overseas as the local industry is unable to accommodate the requirements:

"(... ) we are depending on the supplier from overseas as the local supplier is seems unable to help and meet the requirement (certification) (...) the industry is immature (...)" (case D).

In the same essence, the focal companies are unable to fully ensure the integrity of imported halal raw materials due to the non-uniformity of halal standards and traceability tools. In contrast, food industry production is claimed as almost just-in-time. This suggests that, the more advanced lean practices do not promise better food integrity. In parallel, the rigidity imposed by having limited suppliers in order to tackle the integrity issue do not offer cost advantages towards the focal company. Furthermore, continuous production and push systems cause higher inventory levels and storage. On the same note, one of the major issues in ensuring halal quality is proper segregation to avoid contamination. In this perspective, the halal specific requirement can push lean implementation, which can play a significant role in increasing halal integrity by having organized storage and eventually, a lower total cost.

Associating with normal non-halal food products, halal food production needs to observe and fulfil extra requirements. From the perspective of normal food production, it can be seen as over processing, as additional movement and transport standards are deployed. Thus the competitiveness of halal food in the outer dimension of its target markets is restricted to the extra cost allocated for such requirements. Attributed to the integrity of its wholesomeness, the halal conformance check is crucial to identify any defects (non-halal) on all the materials. The cases are not remote and the focal company needs to be extra vigilant by investing in more hours and labour for mitigation where significant costs are related. "(...) in the year of 2012, a halal certified butter founded containing prohibited elements (swine's DNA). We do not use the butter, but through flyers, JAKIM instruct the firm using it to conduct a ritual cleaning" (case A).

On the other hand, the process of obtaining the halal certification requires 6 months of lead time. The high lead time conflicts with lean practices. Thus, it indicates that lean is not appropriate for this section. Exacerbated by the complexity of the halal food supply chain, the halal food products are vulnerable, as the risk of halal integrity can be jeopardized in various ways while awaiting the certification, as the products are highly dependent on the halal status of all the ingredients and materials used along the supply chain. In the light of this, lean needs to be practised along the supply chain in order to gain benefits for the halal integrity. However, it is highlighted that the local industry is not ready for the lean practices, which leads towards the overseas company; this is more difficult due to the distances, i.e. geographical, cultural, and in terms of power. "(...) the calibre suppliers are not readily available locally that we can have a win-win situation (...)" (case of $C$, Halal Executive).

\section{Practical implications}

The results have showed that the lean implementation in ensuring halal integrity is promising and may yield a preferable output. Even though it is found that lean may have a trade-off with food integrity, the implementation is still possible. As highlighted by Ali et al., ${ }^{18}$ finding the commonness in different sets of implementation may yield a preferable output for the firms. For example, introducing lean as part 
of the meta systems while safeguarding in specific point of production may yield a silo benefits towards the current process. Further lean testing on the proper halal process and food allergen perspectives can be regarded as potential research in the field.

However, according to the Ali et al., ${ }^{19}$ halal food supply chain integrity is depending upon one another; therefore the lean implementation is best to be implemented in the whole supply chain to reap the full potential benefits. As argued under Complimentarily Theory, there are synergy value in all process if it is being implemented together. ${ }^{19,20}$ Notwithstanding that, the complex halal food supply chain and its production impede the lean implementation. This research is suggesting that the managers to championing integration in the supply chain in prior implementing lean in its supply chain. ${ }^{21}$ Therefore, as a starting point for implementation of lean in the halal industry is to start at the functional-silos of the production. In light of this, the future study can investigate the readiness of the halal industry in implementing lean in its total supply chain so as to affect the food integrity.

\section{Conclusion}

This paper shows that a mixed result on the implementation of lean in ensuring halal food supply chain integrity. In specific, the lean goals in improving food quality and reducing total cost are difficult to achieve simultaneously in the halal food industry. Upholding halal integrity dictates that associated costs are necessary and lean application can only be implemented on certain segments. Furthermore, due to the novelty of lean in the food industry, the paper also highlights the possibilities of lean implementation, i.e. on the aspect other than quality related issues during halal food production.

\section{Acknowledgements}

The authors thank the anonymous reviewers for their invaluable comments and the University Kebangsaan Malaysia for the funding to conduct the study under the Grant No. GGPM-2017-001.

\section{Conflict of interest}

The author declares no conflict of interest.

\section{References}

1. Ali MH, Tan KH, Pawar K, et al. Extenuating food integrity risk through supply chain integration: the case of halal food. Industrial Engineering and Management Systems. 2014;13(2):154-162.

2. Bonne K, Vermeir I, Bergeaud-Blackler F, et al. Determinants of halal meat consumption in France. British Food Journal. 2007;109(5):367-386.

3. Campbell H, Murcott A, MacKenzie A. Kosher in New York City, halal in Aquitaine: challenging the relationship between neoliberalism and food auditing. Agriculture and Human Values. 2011;28(1):67-79.

4. Roth AV, Tsay AA, Pullman ME, et al. Unraveling the food supply chain : strategic insights from china and 2007 recalls. Journal of Supply Chain
Management. 2008;44(1):22-39.

5. Womack JP, Jones DT. Lean Thinking: Banish Waste and Create Wealth in Your Corporation. 1996.

6. Lehtinen U, Torkko M. The lean concept in the food industry : a case study of contract a manufacturer. Journal of Food Distribution Research. 2002;36(3):57-67.

7. Heymans BB. Lean manufacturing and the food industry. Continous System Improvement. 2009. p. 1-6.

8. Wasserman N. Revisiting the strategy, structure, and performance paradigm: the case of venture Capital. Organization Science. 2008;19(2):241-259.

9. Ali MH, Tan KH, Ismail MD. A supply chain integrity framework for halal food. British Food Journal. 2017;119(1):20-38.

10. Tunçer B. From Farm to Fork? Means of Assuring Food Quality; An Analysis of the European Food Quality Initiatives. IIIEE Reports; 2001. p. $1-138$.

11. Cox A, Chicksand D. The limits of lean management thinking: multiple retailers and food and farming supply chains. European Management Journa. 2005;23(6):648-662.

12. Langhauser K. Are You Playing The Lean Game? Food Manufacturing. 2008.

13. Mahalik NP, Nambiar AN. Trends in food packaging and manufacturing systems and technology. Trends in Food Science \& Technology. 2010;21(3):117-128.

14. Eisenhardt K. Agency theory: an assessment and review. Academy of Management Review JSTOR. 1989;14(1):57-74.

15. Yin RK. Case Study Research: Design and Methods. In: Bickman L, et al. editors. Essential Guide to Qualitative Methods in Organizational Research. USA: Sage Publications; 2009.

16. Spear S, Bowen H. Decoding the DNA of the Toyota production system. Harvard Business Review. 1999. p. 96-106.

17. Talib M, Johan M. Issues in halal packaging: a conceptual paper. International Business and Management. 2012;5(2):94-98.

18. Ali MH, Suleiman N. Sustainable food production: insights of malaysian halal small and medium sized enterprises. International Journal of Production Economics. 2016;181:303-314.

19. Ali MH, Zhan Y, Alam SS, et al. Food supply chain integrity: the need to go beyond certification. Industrial Management \& Data Systems. 2017;117(8):1589-1611.

20. Mishra AA, Shah R. In union lies strength: collaborative competence in new product development and its performance effects. Journal of Operations Management. 2009;27(4):324-338

21. Ali MH, Makhbul ZM, Tan KH, et al. Augmenting halal food integrity through supply chain integration. Jurnal Pengurusan. 2016;48:21-31. 